Ana l. Leal Lobato*

\title{
The (Inter)cultural Missing Link in Conference Interpreting
}

\begin{abstract}
The second half of the twentieth century brought about increased international contacts between people from different origins, which led to changes in the translation studies landscape, impacting conference interpreters as well. Although interpreting scholars acknowledge that interpreters are both linguistic and intercultural mediators, at first glance, culture and intercultural mediation appear to be neglected in the domain of conference interpreting, unlike the domains of community and sign language interpreting.

In this paper, I conduct an analysis on how the established professional discourse and the scholarly literature have portrayed culture and intercultural mediation in conference interpreting. The analysis reveals various conceptualizations of culture and different stances regarding intercultural mediation. Amongst them, reductionist conceptualizations of culture seem to dominate; conceptualizations that have informed the conference interpreting pedagogy. However, this state of affairs contrasts sharply with the current culturally diverse interpreting landscape, what might have an impact on practice and professional identity.
\end{abstract}

Keywords: conference interpreters; conceptualizations of culture; intercultural mediation; scholarly literature;

professional discourse

\section{Setting the scene}

The second half of the twentieth century has been characterized by a profusion of international contacts between people from different origins. This phenomenon has led to changes in the interpreting landscape, giving rise to new needs (Garzone/Viezzi 2002: 5). Since the 1990s, interpreting has increasingly been considered a service no longer restricted to an elite minority (Viezzi 2013: 277); a service that consists in "the task of mediating communication between interactants of different linguistic and cultural backgrounds designed to fulfil a need" (Pöchhacker 2001: 421).

As with many other disciplines, interpreting studies, and the wider discipline of translation studies, have not been oblivious to poststructuralism, witnessing a shift from text to context, from colonial to postcolonial, and from language to communication and culture. The academic interpreting community seems to agree that interpreters are both linguistic and intercultural mediators $^{1}$. But how do conference interpreters address intercultural mediation? Do all interpreting professions attribute the same importance to cultural aspects? And more significantly, what are the most common conceptualizations of culture?

In this paper, I conduct an analysis of how the established professional discourse of the International Association of Conference Interpreters (AIIC) and the scholarly literature on conference

1 In the literature, we can find the terms 'cultural mediator', 'cross-cultural mediator', and 'intercultural mediator'. For coherence purposes, and without entering into an ideological-conceptual debate, I will be using the term 'intercultural mediator' (except in literal citations), in line with the latest definition proposed in the literature (Katan 2013).

\footnotetext{
* Ana l. Leal Lobato

Aarhus University

School of Communication and Culture Spanish Business Communication

E-mail: analeallobato@cc.au.dk
} 
interpreting have portrayed culture and intercultural mediation. Against this backdrop, conclusions can be drawn as to which conceptualizations of culture and intercultural mediation have been prioritized and as to the implications thereof for the profession of conference interpreter in the 21 st century. Section 2 presents an analysis of the interpreter role throughout history in connection with intercultural mediation, focusing specifically on the origin of the modern profession of conference interpreter. Section 3 contains a brief overview of the main paradigms in the study of culture and intercultural mediation from fields outside translation studies, which will serve as the theoretical framework for the analysis. Section 4 presents an analysis of the conceptualizations of culture and intercultural mediation in both the conference interpreting professional discourse and scholarly literature, paying special attention to main theoretical frameworks, ethnographic research, and training manuals. A concluding section with the main implications closes the article.

\section{Intercultural mediation and interpreters throughout history}

Interpreting, as a practice, has evolved at the mercy of the rises and falls of history. Throughout the centuries, interpreters have always been commended to bridge divides between different people, with all that this entails in terms of allegiances and treachery, depending on who tells the story and to whom the story is told. The literature on the history of the interpreting profession illustrates how prominent the interpreter's role of intercultural mediator is - albeit the notion of culture in intellectual inquiry did not emerge until the end of the 18th century (Jenks 1993/2005: 7); it contains accounts of different cultural, historical, and context-specific forms of intermediaries whose mission was to bridge the linguistic and cultural divide between people (noteworthy examples are Roland 1999, Bowen/Bowen 2008, Torikai 2009, Delisle/Woodsworth 2012, Valdeón 2013, Fernández Ocampo/Wolf 2014, Baigorri-Jalón 2015, and Takeda/Baigorri-Jalón 2016, to name a few). The emergence of interpreting studies as an academic discipline from the 1950s onward contributed to the professionalization of the trade, which gave rise to a debate on the theory and practice of conference interpreting in academic circles (Bowen 2012: 279). Nevertheless, in order to understand the current profession of conference interpreter, it is essential to go back to "the primary sources of the function of interpreting", to use Baigorri-Jalón's words (2015: 11).

For the purpose of this section, it is not my intention to conduct a socio-historical analysis of the conference interpreting profession- a task undertaken elsewhere (see Gentile 2017, Zwischenberger 2017) - but rather to focus on how culture and intercultural mediation have been conceived in connection with the interpreters' role and the shaping of the profession.

That interpreting is one of the oldest trades in the world is a truism. However, a review of historical accounts should work as a reminder that interpreters are "creatures of their time" and, as such, their role and attitudes need to be analyzed in connection with the context in which they lived (Cronin 2003: 106-111). Historical accounts show that the interpreters' role went beyond mere transfer between two different languages. For example, in his review of the interpreting profession, Baigorri-Jalón (2015) informs us about historical figures such as Tiang Gong, an interpreter in first-century (AD) China, who played the roles of 'cultural ambassador', interpreter, and 'facilitator' for the Chinese authorities when civilizing the barbarians. In the 12th and 13th century Iberian Peninsula, the alfaqueques acted as 'cross-border mediators' ransoming captives during the Christian crusades, and in the Ashanti Kingdom (present day Ghana), the Okyeame, or "king's linguist", was a figure in charge of performing oral 'intralingual' translation for chiefs. In the 18th century, dragomans were in charge of 'facilitating diplomatic relations' between Western European rulers and the Ottoman Empire (Bowen 2012: 275). In all these accounts, the expressions 'mediator', 'cultural ambassador', and 'facilitator' are commonplace and explicitly acknowledge an intercultural mediation role.

During the Spanish colonization of the Americas in the 16th century, the case of Doña Marina, La Malinche, conquistador Hernando Cortés' interpreter, is paradigmatic in the sense that it has aroused ambivalent responses due to her role as a linguistic and intercultural mediator in a colonial setting (Cronin 2002: 392). When conceptualizing La Malinche's role, the concept of inter- 
mediary has been crucial (see Valdeón 2013). In fact, her role as a mediator has been studied by historians and translation scholars alike. Nonetheless, some scholars emphasize her role as cultural intermediary or mediator, on the basis of historical accounts, arguing that La Malinche was subjected to specific circumstances, whereas others, particularly a number of translation scholars, are very critical of her role, accusing her of betrayal of her own people, and have used her image as a metaphor to fulfil their own political agendas (Valdeón 2013:159). Particularly relevant for the purpose of my analysis are the different narratives of mediation that are enacted depending on who conducts the analysis, how, and for which purposes. It would not be misbegotten to suggest that the often competing narratives revolving around the ambivalent role of interpreters, as exemplified by La Malinche, might have tainted the perceptions of intercultural mediation in the field of interpreting in general and in conference interpreting in particular.

Moving forward in time, the "diplomacy by conference era", the precursor of modern conference interpreting (Baigorri-Jalón 2015:18), was inaugurated in the 19th century, with the consolidation of the nation state and the surge of nationalisms. Very relevant for our field is the fact that nationalisms usually involve a strict association of one language variety with membership in one national community, an instance described by Kramsch as linguistic nationism (1998: 72). Since the end of the 19th century and during the post-World War II period of nationalistic international multilingual negotiations (Roland 1999: 132), diplomat interpreters became the visible head of the emerging interpreting profession and enjoyed a great deal of recognition and credibility (Delisle in Introduction to Roland 1999: 4), always associating the interpreter with the nation-language pair.

Regarding the current Western profession of conference interpreter, there is widespread agreement that it emerged during the 1940s-1950s with the institutionalization of interpreter education, the introduction of simultaneous interpreting during the Nuremberg Trials in the 1940s (Bowen 2012: 255), and the foundation of the International Association of Conference Interpreters (AIIC) in 1953. Coinciding with the beginning of the professionalization process of conference interpreting, qualities such as neutrality and impartiality became commonplace in the recounts on and by conference interpreters (Pöchhacker 2016: 169), a trend that was replicated at the end of the 1970s and at the beginning of the 1980s, with the professionalization of sign language interpreting (Roy 1993/2002: 348). It seems that for both sign language and conference interpreting, the process of professionalization was accompanied by a praise of neutrality and impartiality and, perhaps, as a consequence of that, a disregard for intercultural mediation, as these three instances are incompatible; a position that still has a resonance in conference interpreting (for a more detailed discussion, see Kondo et al. 1997).

What is most intriguing is that Roland (1999) in her Interpreters as diplomats: a diplomatic history of the role of interpreters in world politics avoids the term 'culture' when referring to differences between nations and peoples in connection with the interpreter's job. In that vein, Roland speaks about "semantic misunderstandings between the Chinese and the British" (1999: 93); "semantic hassle between the Chinese and the Americans" (1999: 100); "perplexities" in the relations between the West and China at three levels: "the mechanical, the philosophical, and the ideological" (1999: 98); and "the psychology of foreign countries" (1999: 144). One of the few explicit references to culture is the following statement: "infinitely harder to surmount are the psychological and cultural differences, of which language is a mere reflection" (1999: 119), where she acknowledges the existence of underlying deep structures to language that affect interactions. Even Delisle in the preface to Roland's book praises the active intermediary role of diplomatic interpreters, highlighting their linguistic abilities and omitting any explicit reference to culture:

With judicious intervention, interpreters can help naïve, ignorant clients avoid otherwise costly blunders. Although 'their skills are linguistic' and their principal function is to facilitate communication, interpreters are far 'more than simple relayers of speech'. This power stems from the considerable credibility enjoyed by the competent, reputable, neutral and impartial interpreter (Delisle in Introduction to Roland 1999: 4, emphasis added) 
This brief review of the interpreter's role throughout history evidences that interpreters are both linguistic and intercultural mediators. However, authors such as Roland and Delisle seem to avoid the term 'culture'. Not in vain, the anthropological field of the 1980s-1990s outlawed the use of the word 'culture' due to the so-called "anthropological taboo" (Sewell 1999: 38). Notwithstanding, the themes and types of research involving conference interpreters reflect this tendency, as the next sections will evidence.

\section{Concepts of culture and intercultural mediation outside translation studies}

As previously stated, the aim of this article is to review conceptualizations of culture and intercultural mediation in conference interpreting. However, as I will be drawing on concepts from disciplines outside translation studies, it is worth doing a brief review of the main paradigms that inform adjacent fields, and which will serve as the theoretical underpinning of my analysis. By no means does this review intend to be exhaustive, nor is it the aim of the present article; therefore, I will only focus on three major conceptualizations of culture that have permeated discourses in interpreting studies. The first conceptualization, inspired by the German intellectual tradition, conceives culture as "the pinnacle of human creative achievement" (Jenks 1993: 9), in the sense of the higher intellectual processes associated with the arts, music, or literature. In Risager's words, "culture with a big/capital C" (2007: 40). As a result, those who have culture with a capital C are "cultured persons" (Goddard 2005: 63-64), like, for instance, conference interpreters are assumed to be.

But culture can also be understood as a social category, in the broader anthropological sense of "the whole way of life of a people" (Jenks 1993: 12). In this sense, culture can be defined as a shared system of symbols and meanings (Geertz 1973) or practices (Clifford/Marcus 1986/2010), two approaches that are complementary, given the complexity and fluidity of the phenomenon (Sewell 1999:47). Therefore, culture is understood as behaviors and values in everyday interaction, that is, "culture with a little/small c" (Risager 2007: 40). Conceiving culture as a shared system of symbols, meanings, and practices inevitably implies a certain locatedness, what Wierzbicka calls "place-related culture" (2005: 585), which has traditionally revolved around the notion of countries and/or nations. Therefore, a recurrent trend is correlating culture with national attributes, as in the pair Spain-Spanish culture. Under this banner, there are two main approaches, one that tends to perceive culture as static, a homogeneous and closed system, inspired by Durkheim's structural-functionalist tenets, and another that views culture as a dynamic, heterogeneous, and open entity, inspired by Weber's social-action theory (Holliday 2011: 17). The first approach has been very prolific and had much influence in the development of the field of intercultural communication during the 1960s in the US (Rogers et al. 2002:11). Representatives of this paradigm are scholars such as E. Hall (1976/1989) with his iceberg analogy, Triandis (2001), who developed the theory about individualist and collectivist cultures, and Hofstede (1984) with his theory of cultural dimensions across nations.

However, these theories have received criticism for being essentialist and determinist. This criticism led to alternative, non-essentialist views on culture, inspired by postmodern and postcolonial theories that tried to examine culture through a critical lens. This exercise resulted in the emergence of the discipline of cultural studies, which offers the third big approach to examine culture, that is, as a site of contested meaning (Sorrells 2013: 10). Among the representatives of this approach are S. Hall (2008) and his theory of hybridization and cosmopolitanism from below, Kumaravadivelu (2008) and his 'cultural realism' in the field of language teaching, and Holliday (1999: 240) and his concept of 'small culture'. The advantage of this conception is that it is nonessentialist, as it is not related to ethnic, national, or international entities; it rather relates to any cohesive social grouping, such as organizational culture or Deaf culture. Besides, small cultures manifest themselves at a discoursal level, where ideology plays an important role (Holliday 2011: 15). This conception is very relevant to interpreting studies, as we will see later, and has much potential when conceptualizing both the role and the training of current conference interpreters. 
Regarding intercultural mediation, from the corner of cross-cultural psychology, Bochner (1981: 3) distinguishes between two types of mediating roles: the 'mediator-as-translator' and the 'mediator-as-synthesizer', and suggests that:

The purpose of the mediator-as-translator is to represent one culture to another faithfully and thereby
contribute to mutual understanding and accurate cross-cultural knowledge. The purpose of the media-
tor-as-synthesizer is to reconcile disparate cultural practices, this type of mediation having special re-
levance to exchanges from which some action is to follow.

As we will see, the first mediating role, as its name reveals, has resonated especially in translation studies. Furthermore, in relation to social psychology, Taft (1981: 53) presents a definition of the intercultural mediator, highlighting her/his role as a communicator:

\begin{abstract}
A cultural mediator is a person who facilitates communication, understanding, and action between persons or groups who differ with respect to language and culture. The role of the mediator is performed by interpreting the expressions, intentions, perceptions, and expectations of each cultural group to the other, that is, by establishing and balancing the communication between them. In order to serve as a link in this sense, the mediator must be able to participate to some extent in both cultures. Thus, a mediator must be to some extent bicultural.
\end{abstract}

Again, this definition also resonates in the translation-studies literature (see, for instance, SnellHornby 1995).

The analysis in section 4 will evidence how and when these different conceptualizations and definitions have been used in the professional and scholarly literature on conference interpreting.

\title{
4. Culture and intercultural mediation in conference interpreting
}

This section provides an overview of the different conceptualizations of culture and intercultural mediation that can be found in the conference interpreting literature, including professional discourse, scholarly literature and training manuals.

\subsection{The professional discourse}

I will now examine how the established professional discourse on conference interpreting depicts culture and intercultural mediation.

AIIC is currently the main authority of the conference interpreting profession worldwide (Boéri 2015: 31). Furthermore, AIIC had a tremendous influence in shaping the professional ethos of conference interpreters; ethos understood as "the consensual definition of their role and function" (Boéri 2015: 30). Therefore, in an attempt to locate the status of culture and intercultural mediation in connection with the professional ethos of conference interpreters, I will use AIIC's main tool to communicate with the world, its website, as material for analysis. I will only analyze the first three levels of hyperlinks, where AIIC communicates its vision on interpreting.

On AIIC's homepage, under the tab Interpreting explained, subheading Where interpreters work, it reads (AIIC 1998, emphasis added):

(1) Conference interpreters serve the demand for high-quality interpretation services from international organizations or business clients who require seamless communication 'across languages and cultures'.

Example (1) reflects a widely accepted scholarly definition of interpreting: "interpreting is performed 'here and now' for the benefit of people who want to engage in communication across barriers of language and culture" (Pöchhacker 2016: 10, emphasis in original).

Under the subheading Conference interpreting, it reads (AIIC 2012a; bold in original, emphasis added):

(2) The modern practice of conference interpretation is usually considered to date from the Nuremberg trials of 1945-1946. But throughout history people of 'different languages and cultures' have made use of interpretation to communicate with and understand each other. 
(3) Interpreters have always been involved in the development of international trade and 'cultural exchange'.

(4) But it was only towards the end of the 19th century, with the appearance of the first international organizations and of regular conferences, that some people were able to make a living as interpreters.

(5) With the emergence of 'simultaneous interpretation' in the middle of the 20th century the profession developed considerably and was shaped accordingly.

(6) Conference interpretation is conveying a message 'spoken in one language into another'. It is practiced at 'international' summits, 'professional seminars', and bilateral or multilateral meetings of 'heads of State' and Government.

(7) Conference interpreters also work at meetings between chief executives, social and union representatives, at congresses and meetings, and so on.

The statements above indicate the following:

1) There is a common association between conference interpreting and simultaneous interpreting (5), involving high-profile participants in international institutional-like settings (4)-(7). As a matter of fact, scholarly literature identifies conference interpreting with the international end of the interpreting spectrum, versus the intra-social/community one (Pöchhacker 2016: 17). As a consequence, culture does not appear to be as relevant as it is for settings in the intra-social interpreting spectrum, which are usually associated with a dialogic mode of interpreting.

2) Although conference interpreters are expected to provide 'seamless communication across languages and cultures' (1), in the remaining excerpts, AIIC does not further develop the notion of culture, in contrast to linguistic aspects (6). Besides, culture is only mentioned in general terms to refer to the interpreter's role, placing special emphasis on the historical image of the interpreter (2)-(3), which might be interpreted as if his/her role as intercultural mediator was particularly important in the past, especially in the period up to the beginning of the professionalization process. In any case, in these excerpts, culture only refers to the high intellectual process and anthropological concept of culture.

Further down the webpage, AIIC (2012a; bold in original, emphasis added) prescribes the following skills for a conference interpreter:

(8) Interpreters must have complete mastery of their 'working languages', including an excellent command of their 'native language'. They need an immediate grasp of their 'passive languages' and a well-developed capacity to express themselves in their 'own language'.

The list goes on without including any other specific reference to culture or intercultural mediation abilities. Only under the heading Working languages do we find another reference to culture (AIIC 2012b; bold in original, emphasis added):

(9) As well as speaking their 'mother tongue' perfectly, conference interpreters perfectly understand one or more 'other languages' and the 'culture that lies behind them'.

This statement clearly alludes to the anthropological sense of culture, and restricts culture to a specific language and, most probably, to a particular geographical location, as language usually correlates with country or nation; so culture is understood as national attributes.

An interesting line of inquiry is to consider how the professional field of conference interpreting depicts other interpreting settings. The field of interpreting, as many other fields, did not escape from a "boundary work" that introduced clear boundaries differentiating 'us' from 'them', which led to establishing different categories of interpreting professions (Grbić 2010: 111). Examining what one group has to say about another may help shed light on what one's own identity should or should not be. Therefore, looking at what AIIC has to say about other interpreting professions can be revealing. 
Since, at least, 2011, the AIIC website has contained a page called Related professions, which accounts for interpreting in other settings. Of interest here is the brief definition of community interpreting (AIIC 2011; bold in original, emphasis added):

(10) People may call on interpreters to help them communicate with the authorities or official bodies - a role referred to as community interpreting. Interpreters may assist contact between 'refugees' and administrative services, between 'people in difficult situations' and 'social workers', between patients and doctors or 'hospital services' (medical interpretation, 'police services'), and so on. In this kind of interpretation, 'social, cultural and human factors' all have a crucial part to play in the interpreting process, as do the interpreter's specialized knowledge and professional ethics.

AIIC acknowledges the importance of cultural aspects in connection with 'refugees', 'people in difficult situations', 'social workers', and 'hospital and police services'. Here culture does not appear to be shielded by a language - and often, and by extension, a nation-state - as it does in the description of conference interpreting; here culture appears to be something different, a token associated with problematic social situations. Some scholars, like Mikkelson (2009), suggest that a categorization of different interpreting professionals might bring about an unnecessary divisiveness within the profession. Mikkelson claims that one sign of this divisiveness is the myth that cultural differences are only relevant to community interpreters. Indeed, the aforementioned boundary work makes culture - an essential factor for community interpreters - all of a sudden irrelevant for conference interpreters. This absence of culture in the established professional discourse leads to a "culture blindness" in the field, to use Goddard's words (Goddard 2006: 2). Although briefly mentioned in the heading of the definition of conference interpreters (1), culture is not elaborated on, and hence, it is not problematized, although current societies and market realities are complex and diverse.

\subsection{Culture and intercultural mediation in the scholarly literature}

Turning to the scholarly literature, Cronin, in his celebrated essay The empire talks back: orality, heteronomy and the cultural turn in interpreting studies, made a call for: "the development of a 'cultural turn' in interpreting studies [...] a material history of interpreting that would examine all forms of interpreting as they are grounded in the economic, political, and cultural conditions of people's lives" (2002: 391; emphasis in original). In other words, he made a call for a cultural turn through the lens of postcolonialism in the study of interpreting.

Cronin also argues that interpreting studies, a minoritized field within translation studies, also minoritizes other interpreting paradigms in favor of conference interpreting (2002: 389). Over the last decades, however, research on neglected fields which involve minorities, such as healthcare, court, police, and sign language interpreting, has flourished. The new research trends account for sociocultural aspects of the interpreted communicative interaction and focus on the mediators rather than the products, which has led to the so-called sociological turn (Inghilleri 2005, Pym et al. 2006, Wolf/Fukari 2007). Not in vain, sociocultural aspects have been the object of extensive research in relation to norms, ethics, and professionalization, but also in relation to assessing interpreters' role as co-constructors and intercultural mediators in the interaction (Angelelli 2004, 2008; Berk-Seligson 2002, Davidson 2000, 2001; Mason 2001, Mesa 2000, Metzger 2000, Roy 1999, Wadensjö 1998). Furthermore, research on cultural aspects in sign language and community interpreting has flourished, evincing the accomplishment of the cultural turn in community interpreting, as Rudvin (2006) claims.

Concurrently, research on simultaneous conference interpreting generally maintained its focus on topics associated with the simultaneous mode, such as cognitive aspects, drawing on psycho- and neurolinguistics paradigms (Diriker 2004: 1-2). This situation is due to the traditional identification of conference interpreters with the simultaneous mode (Diriker 2015: 79). Notwithstanding the general trend, the sociological turn did make its way to the study of conference interpreters: there is a significant body of research focusing on agents, and exploring themes such as norms, role perception, ethics, ideology, and professionalism (Beaton 2010, Dam 2017, Dam/ 
Zethsen 2013, Diriker 2004, 2009; Gentile 2013, 2017; Monacelli 2009, Seeber/Zegler 2007, Zwischenberger 2017, to name a few). However, the issues of culture and intercultural mediation, which are closely related to the discussion on the interpreter's role (Torikai 2010: 86), appear generally to be disregarded. As a testament to this, bibliometric studies on interpreting research do not list cultural or mediation aspects as research topics of interest (Gile 2001, Pöchhacker 1995, Liu 2005), evincing a scarcity of research in this area. As a matter of fact, the recent update of the handbook Introducing Interpreting Studies (Pöchhacker 2016), as well as the Routledge Encyclopedia of Interpreting Studies (Pöchhacker et al. 2015), do not include any specific entries for the key term 'intercultural mediation', in contrast to the Handbook of Translation Studies (Gambier/ Van Doorslaer 2013).

In 1994, the International Conference on Interpreting in Turku: what do we know and how? convened a panel on intercultural communication. This panel discussed, amongst other issues, the hot topic of intercultural mediation, launching a call to have an open and inclusive debate on the matter (Kondo et al. 1997). Oddly enough, pioneering publications addressing intercultural aspects in the training of conference interpreters flourished during the late 1970s and 1980s (Arjona 1978, Brislin 1978, Bowen 1985), a period that was followed by a drought. From the 1990s onwards, publications dealing with intercultural mediation and conference interpreting have been scattered. Nonetheless, there have been attempts to re-launch the debate on intercultural mediation or to draw more attention to the topic (Kondo 1990, Straniero 1998, Levy-Berlowitz 2008), studies on the role of the intercultural mediator (Marrone 1993, Bahadır 2004, Katan 2004, AlZahran 2007, Eraslan 2008, Torikai 2010), case-studies of intercultural communication challenges for specific language pairs (Scaglioni 2013, Bourne 2016), and pedagogic proposals to teach intercultural aspects (Katan 2004, Morell 2011, Bourne 2015). Nevertheless, all in all, we can conclude that the cultural turn did not seem to materialize in conference interpreting.

In order to analyze how culture has been portrayed in the literature on interpreting, it is crucial to examine the notions of culture and intercultural mediation in relation to role, since they are inevitably intertwined. Both concepts will be briefly reviewed in the next subsection, which by no means intends to be exhaustive, but an overview of various positions.

\subsubsection{Theoretical frameworks on culture and intercultural mediation in the scholarly literature}

Important elaborations on intercultural mediation have been made by Katan (2013) and Bahadır (2004). For the purposes of this paper, their proposals are worth analyzing because of their innovative theoretical frameworks and their more interventionist position regarding intercultural mediation.

On a theoretical level, Katan is perhaps the most prolific scholar in the field of interpreting and intercultural mediation. He takes a stance in favor of intercultural mediation and draws on interdisciplinary literature from anthropology, sociolinguistics, intercultural communication, and intercultural training. Some of Katan's works may be branded essentialist, since he draws inspiration from highly criticized determinist cultural theories (see for instance Katan 2004: 245). Nonetheless, his effort to bridge the gap between translation studies and intercultural communication is commendable, as is the pragmatism of his proposed pedagogic models. In Translating cultures, Katan (2004) views translational action as a cross-cultural transfer in the Vermeerian sense, where culture involves knowledge, proficiency, and perception (Snell-Hornby 1995: 42). He denounces that, at least in the West, translators and interpreters are still very much perceived as "walking dictionaries" (Katan 2004: 22) and defends the need to raise awareness of the importance of the cultural factor and the ideological environment (Katan 2004: 66). Katan claims that there are competing definitions of culture which represent different levels of culture (Katan 2008: 78). In that vein, following an anthropological logic, he distinguishes between four levels of culture: 1) "Technical culture or shared encyclopedic knowledge", or the "first cultural frame" that corresponds to a "humanist concept of culture" (2008: 79). This is culture with a big/capital 
$\mathrm{C}$, as in artistic works and practices, as well as the knowledge acquired through formal instruction, in the sense of a cultured person. 2) "Formal culture", which responds to norms and behaviors that are normal or appropriate in a particular culture - culture with a little/small c - where the concepts of skopos and functions play an important role. 3) "Informal culture", which refers to the out-of-awareness cognitive systems and values, the invisible culture according to E. Hall (2008: $83)$. With this idea in mind, Katan advocates the idea of translators and interpreters as "proficient and visible cultural interpreters/mediators" (2004: 4). 4) "Societal power relations" (2008: 87), which is the fourth level of culture and is located outside the scope of the anthropological model. This conceptualization is rooted in critical postcolonial thinking and accounts for issues of cultural identity, power differentials, and ideologies: what I interpret as being in line with the third conceptualization of culture as a site of contested meaning.

Moving on to realizations of intercultural mediation, Katan (2013: 85) observes two types of intercultural mediation: 1) in the realm of language and communication, and 2) in the realm of cultural identity, and he takes as a starting point the above-mentioned four levels of culture. The first level, the language and communication realm, is the more superficial level, where interpreters conduct a "lingua-cultural intervention", such as in the translation of culturemes (Katan 2013: 85). This conceptualization is reminiscent of what Agar (1994) calls "languaculture", which refers to the indissoluble marriage between language and culture, because "using a language involves all manner of background knowledge and local information in addition to grammar and vocabulary" (Agar 2006: 1). In this realm, interpreters also conduct an "intercultural intervention" at a deeper level, where beliefs, values, and perceptions of the two cultural groups play an essential role and interpreters need to mediate (Katan 2013: 86). Finally, in the deepest level, the cultural identity realm - inspired by postcolonial thinking - intercultural mediation involves mediation in terms of identity and roles of all the participants in the event, including the translator/interpreter. Katan (2013: 87) states that this realm has given rise to controversial debates, such as on the dichotomy between mediator and advocate or activist. On this level, we recognize the role of the 'mediator-as-synthesizer', who tries to reconcile divergent cultural practices to reach an understanding; a function that is regarded with suspicion across the field of interpreting studies.

Perhaps due to the different conceptualizations and positions, especially the fourth level of culture (societal power relations) and the second level of intercultural intervention (cultural identity level), most translation and interpreting institutions and practitioners consider full intercultural mediation as unprofessional, which has resulted in new professions that respond to the intercultural mediation needs of institutions and markets (Katan 2013: 89). Noticeably, Katan defends a wider concept of 'intercultural mediator' and he explicitly disassociates it from the image of the public service interpreter. In spite of his wider call for intercultural mediation across the interpreting profession, his work does not seem to resonate among the so-called conference interpreters.

Similarly, Bahadır (2004) conceives translatorial action as cross-cultural transfer in the Vermeerian sense. Following Göhring's ideas from the contrastive discipline of cross-cultural communication (Snell-Hornby 1995: 40), Bahadır advocates the idea of the translator/interpreter as a professional who acts interculturally rather than only possessing the knowledge: a sort of "postcolonial mini-ethnographer" (2004: 809). According to Göhring (1977 in Snell-Hornby 1995: 40), culture amounts to knowledge, proficiency, and perception, is connected with behavior, and is dependent on expectations and norms, both in social behavior and language use. Authors from other fields, such as Bochner (1981) and Agar (1994), draw a parallel between the professions of anthropologist/ethnographer and translator/interpreter: Bochner, with his concept of 'mediatoras-translator', and Agar, who suggests that the product of ethnography is the translation between two different languacultures (2006: 6). Conversely, I argue, emulating Bahadır, that the interpreter also adopts the role of ethnographer, mediating between two languacultures, with the aim of rendering a translation to enable communication. Adopting such an approach has implications in terms of professional identity and training. 
Bahadır suggests approaching translatorial action with an anthropological gaze to humanize the profession. She proposes the model of the "critical interpreter-ethnographer" (2004: 813) as the ideal intercultural mediator against the backdrop of postcolonialism. In this sense, her postcolonial concept of culture fits Katan's fourth level of culture and second level of intercultural intervention, where ideology and identity play an important role. Bahadir (2004) argues that her model should be used to conceptualize the professional identity of translators and interpreters across the board and to establish a universal pedagogical framework for training. In spite of her universalist approach to the interpreting profession as a whole, Bahadır has developed her work in community interpreting.

\subsubsection{Concepts of culture and intercultural mediation in ethnographic research}

Although scarce, there are some exceptional examples of ethnographic research on conference interpreters and intercultural mediation: Al-Zahran (2007), Torikai (2009), Eraslan (2011), and Bourne (2015). Significantly, this pioneering research was conducted with conference interpreters of non-Western languages: Arabic, Japanese, Turkish, and Chinese, as the cultural difference when compared to English and the West was deemed worth investigating. Al-Zahran's and Eraslan's results apply specifically to consecutive conference interpreters, while Torikai and Bourne study conference interpreters in general. The concepts of culture and intercultural mediation used by Al-Zahran and Torikai are worth analyzing, because these concepts, in the light of Katan's and Bahadır's theoretical frameworks, evidence the current state of schizophrenia of the conference interpreting scholarly discourse. I will not touch upon Bourne's work on intercultural challenges in Chinese-English conference interpreting applying E. Hall's, and Hofstede's contested theories, but I will briefly refer to Eraslan's work.

Torikai $(2009,2010)$ conducted oral history research with five Japanese diplomatic simultaneous interpreters in the post-World War II period, examining their perceptions of culture and intercultural mediation, and analyzing their role. Torikai reached the conclusion that interpreters are like kurogo in the Japanese kabuki theater: an assisting figure dressed in black. Instead of being an invisible linguistic conduit, an interpreter is fully present wearing a professional black mask and reminds the parties that s/he plays the role of "coordinator on an intercultural stage" (2009: 180). According to Torikai, an interpreter is, thus, an expert in intercultural communication, who mediates intercultural encounters, in line with Katan's second level of intercultural intervention.

Focusing on the Japanese/Japan-English/USA linguistic and cultural pair, Torikai approached culture as a whole composed of knowledge, proficiency, and perception, conceiving the interpreter as a bilingual and bicultural agent in the Vermeerian sense (Snell-Hornby 1995: 42), or as Taft suggests in his definition. The pairs under scrutiny are the Japanese culture associated with Japan, and American English linked to the USA. Here culture is completely place-related and based on national attributes. A striking result is that Japanese interpreters seemed to be indifferent to culture ("what they said"), but in practice they were acting as intercultural mediators ("what they did") (Torikai 2010: 91). Torikai's work is a fine illustration of competing discourses: on the one hand, the interpreters' self-presentation based on the meta-discourse of the profession and reminiscent of the conduit metaphor that minimizes any kind of intervention and, particularly, intercultural intervention and, on the other hand, the interpreters' actual practices as elicited from their narratives (for a detailed discussion on competing discourses, see Diriker 2004). Another example of competing discourses with regard to intercultural mediation is Eraslan (2008: 25), who reached a similar conclusion to Torikai's in her study of Turkish interpreters working in the consecutive mode.

In the second reference under scrutiny, after conducting a survey on the role of conference interpreters, Al-Zahran (2007) concluded that Arabic-English consecutive interpreters in conference settings act as intercultural mediators. Al-Zahran (2007: 153) advocates the role of the consecutive conference interpreter as "a faithful, accurate and neutral (non-biased/non-partisan/impartial) cultural mediator", thus contesting Kondo's position, which conceives intercultural mediation as an endeavor opposed to neutrality (Kondo et al. 1997: 153). Al-Zahran (2007: 255-256) 
concludes that the consecutive conference interpreter is "an agent for understanding, one who uses his/her knowledge of the two languages and corresponding cultures". His idea of intercultural mediation is in line with Bochner's idea of 'mediator-as-translator'. However, Al-Zahran does not explore or problematize the concept of culture in his theoretical framework, nor does he inquire about the possibly differing understandings of culture and mediation that the interpreter participants might have had when responding to the survey. In fact, most occurrences of the term 'culture' in Al-Zahran's dissertation establish a univocal correspondence with an associated language, as in 'languages and their corresponding cultures' or 'the SL [source language] culture'. The parallelism with AIIC's position is evident: "conference interpreters perfectly understand one or more 'other languages' and the 'culture that lies behind them"' (2012b). This finding leads to conclude that the same restrictive conceptualization of culture is found both in the scholarly literature and in the established professional discourse. At the same time, this conceptualization strictly adheres to Katan's first level of lingua-cultural intervention and, simultaneously, presupposes a stringent place-related component. In addition, Al-Zahran's position seems to follow normative thinking in research on interpreting, treating languages and cultures as separate entities and adopting a monological view on language and mind (Wadensjö 1998: 79).

In my view, by emphasizing the link between, on the one hand, a source language and its corresponding culture and, on the other hand, a target language and its associated culture, Al-Zahran presents too restrictive a concept of languaculture that neither is aligned with the latest developments in cultural and postcolonial studies, nor matches the diverse nature of market realities for conference interpreters in current societies and markets. In fact, as part of my ongoing research (Leal-Lobato, in progress), interviewed professional conference interpreters provided some clear examples of very interventionist intercultural mediation episodes in their everyday professional practice. For instance, in a training session for Latin American police forces given by trainers from the US police forces, the conference interpreters felt the need to instruct the US trainers about how to manage the interaction with the audience in order to enhance communication. The audience was composed of Latin American male and female police officers of different ranks. To the dismay of the US trainers, rank order and gender were preventing young Latin American female police officers from participating actively in the course, which was inspired by a US-American teaching style. The interpreters noticed cultural differences in terms of rank, gender, and teaching styles and advised the trainers to modify their teaching style accordingly. The interpreters, thus, intervened on the level of identity and societal power relations (fourth level of culture), navigating cultural identities and ideology, and adopting a clear role of 'mediator-as-synthesizer', thereby going a step beyond the role of 'mediator-as-translator'.

What is also problematic is perceiving culture as a static, homogeneous, closed system. Adopting this narrow approach, though, is common practice in the conference interpreting realm, where a language is often strictly identified with 'its' corresponding country (and culture) of origin, as evidenced by the EMCI (European Master in Conference Interpreting) Core Curriculum recommendations (see EMCI 2015). Understanding languaculture in such narrow terms is not without peril, as it can lead to, for instance, linguistic nationism, which can involve the exclusive promotion of certain language varieties in conference interpreting programs, such as the centralnorthern variety of European Spanish. Furthermore, this restrictive approach essentializes culture and discriminates against wider understandings of culture that can involve, for example, intrasocietal minority cultures, such as disability culture; subcultures, such as drug culture (Goddard 2005: 58); minoritized cultures, such as indigenous peoples' cultures; or small cultures, such as feminist organizations' culture. Disregarding diverse understandings of culture and the cultural diversity present in the settings where conference interpreters work can be detrimental to the success of the interpreted communicative event (for an illustration, see Leal-Lobato 2017).

Obviously, acknowledging or disregarding this diversity feeds from and back into the pedagogy and training tradition of conference interpreters. As a fundamental piece of scholarly literature, 
conference interpreter education and training manuals are an essential source for the analysis of the conceptualizations of culture and intercultural mediation.

\subsubsection{Concepts of culture and intercultural mediation in training manuals}

Training manuals use different conceptualizations of culture. The following excerpts constitute by no means an exhaustive list, but rather a selection of representative examples from different materials throughout the years.

There are numerous references to the binomial language-culture in direct relation to a country, such as in Herbert's widely-cited The Interpreter's Handbook, where he claims that "the interpreter should be acquainted with the specific culture of the country of the speaker" (1952: 10). The concept of culture as in a 'cultured person' is also profusely mentioned; an observation shared by Angelelli (2000: 42). For instance, Herbert (1952: 20) observes that "he [the interpreter] should in addition have an extremely wide general culture"; and Seleskovitch/Lederer (1989: 228) list having connaissances générales as an essential requirement for interpreters. Another recurring conceptualization of culture is the humanistic notion of culture, or culture with a 'capital C', which can be found in Sawyer's (2004: 48) interpreting curricula, and which prescribes the study of culture in the sense of the art, literature, and history of a nation. All these conceptualizations of culture are place-related and remain in Katan's first level of culture, which represents the less interventionist spectrum of intercultural mediation.

Coinciding perhaps with the cultural turn in translation studies, manuals from the 1990s onward acknowledge the intercultural mediation component of the interpreter's task, albeit rejecting advocacy (for instance, Jones 1998: 3, Sawyer 2004: 38, Setton/Dawrant 2016: 371). Note that Herbert affirms that the essential task of interpreters is "to bring together individuals and groups" (1952: 82), which can be construed as some sort of mediation, although he does not explicitly formulate it as such. In this sense, Jones argues that:

\footnotetext{
communication difficulties are thus much more than pure translation difficulties. The cultural difficulties can manifest themselves both explicitly and implicitly. [...] In all of their work, interpreters must bridge the cultural conceptual gaps separating the participants in a meeting (1998: 3).
}

Jones goes a step further and suggests that "the interpreter should have something of a pedagogical streak, their work being one of continuous explanation and explication" (Jones 1998: 3). However, appealing to neutrality and impartiality, Jones qualifies his statement arguing that adding "information should be provided only if it is indispensable to bridge the culture gaps referred to above: it should in no way involve the interpreter's adding their own point of view to that of the speaker" (1998: 4). Jones has a clear interventionist stance, and his notion of implicit and explicit cultural difficulties is reminiscent of Katan's logical levels of culture, but he never formulates it in terms of 'intercultural mediation'.

Moving on to a recent resource, Setton/Dawrant (2016), in their chapter devoted to professionalism and ethics, allude to intercultural mediation and call it 'optimized interpreting'. They define 'optimized interpreting' as "making the cognitive effects intended by the speaker as [the interpreter] understands them maximally accessible to the interpreter's audience at minimal processing cost, in her projection of the listeners' available contexts" (2016: 351). According to them, optimizing strategies require "an expert command of language, knowledge and intercultural competence" (2016: 200). This optimization is carried out depending on the cultural gap to be bridged, as well as the setting and level of interaction. In this sense, optimization "will be easier and more appropriate to implement in consecutive than SI [simultaneous interpreting]" (2016: 352). This statement echoes Eraslan's and Al-Zahran's research results.

Nevertheless, manuals for conference interpreters, in general, do not include separate sections specifically devoted to intercultural communication or intercultural mediation. Nor do they include any suggestions about how to operationalize intercultural competence, which is in sharp contrast to literature on translator training and translation pedagogy (see Kelly 2005, Tomozeiu/ 
Kumpulainen 2016, as examples). Intercultural skills do not appear to be as central as 'core' interpreting skills. In that vein, Setton/Dawrant, for instance, list "intercultural awareness" as a crosscutting skill to be discussed at "teachable moments" (2016: 80), without systematizing it through an explicit theoretical framework in the curriculum, such as the frameworks proposed by Katan or Bahadir. All in all, the debate on intercultural mediation appears to be an unresolved one. Not for nothing, Sawyer (2004: 4)- along the same lines as Katan (2013: 90)- recognizes the issue of interpreters as "intercultural consultants" to be a challenge in the field of interpreter education.

It may be safely argued that when it comes to intercultural mediation for conference interpreters, clear definitions and rules seem to be lacking, which might lead interpreters to make hasty decisions on an ad-hoc basis. Whether and how this situation can be managed in terms of professionalization and norms is the object of a broader discussion (for a detailed discussion on professionalism, see Dam 2017).

\section{Conclusions and implications}

As has been acknowledged in the literature, interpreters have played the prominent role of intercultural mediators throughout history. Current scholarly definitions suggest that interpreters mediate communication across languages and cultures; yet the concept of culture is not sufficiently developed, or problematized, and the topic of intercultural mediation has been largely neglected in the literature on conference interpreting. A review of the scarce scholarly literature on the topic evidences that there is a pervasive tendency to omit culture. Nonetheless, different understandings of culture and different positions concerning intercultural mediation emerge concurrently, depending on historical period and author.

When it comes to the modern professional conference interpreter, his/her role as intercultural mediator appears to have been silenced, on purpose or inadvertently. In certain accounts, the generalized omission of culture might have its roots in the emergence of the 'anthropological taboo' in the 1980s-1990s that tainted the term 'culture'; or perhaps the purpose has been to dilute the ambivalent position of the interpreter, their slippery "monstrous doubleness" (Cronin 2002: 392), which is clearly exacerbated when acting as an intercultural mediator. Regardless of the reasons, the themes and types of research involving conference interpreters reflect this tendency, resulting in an invisibilization of the cultural dimension and the consolidation of a culture blindness in the field.

In spite of the call for a revision of the role of interpreters as intercultural mediators across the board, most scholarly work on intercultural mediation has resonated with professional communities other than conference interpreters. Furthermore, there appears to be a disregard for cultural aspects in relation to modern conference interpreters, as evidenced by AIIC's professional discourse, which highlights the historical role of interpreters as intercultural mediators, but emphasizes the relevance of culture at the present time only for community interpreters, which exacerbates the invisibility of culture in the field.

However, the evidence of competing narratives on intercultural mediation among conference interpreters, as well as opposing discourses between neutrality and partiality, on the one hand, and mediation, on the other, calls for further research on the perceived and actual role of conference interpreters. Although there is scholarly work that specifically addresses this topic, conclusions seem to be restricted to interpreters working in the consecutive mode. Moreover, the results of some of these studies are based on essentialist conceptualizations of culture that have a narrow view of the notion of languaculture; a view that does not match the reality of conference interpreters in current societies and markets. Regarding training manuals, a lack of consensus about the type and extent of mediation can be observed. As a matter of fact, 'intercultural mediation' does not figure prominently in manuals, only in terms of role and ethics, and it is sometimes subsumed under the wider category of 'mediation'. 
Further research is necessary to account for the diversity of current conference interpreters' practices. Conducting research on conference interpreters from different languacultural backgrounds, including interpreters of Western languages, is essential, because differences do not only arise in distant countries; differences also exist in Western countries, within the same society as people have diverse cultural identities based on gender, ethnic origin, age, or ability, to name only a few relevant features. In this sense, shedding light on different conceptualizations of both culture and intercultural mediation, as understood by researchers, practitioners, and educators ali$\mathrm{ke}$, is necessary. Engaging in a critical debate is crucial in order to adopt an alternative approach to interculturality, emulating the neighboring disciplines of cultural studies and language education. Such an exercise is key to responding to the pressing challenges of the current profession and should resonate in theoretical pedagogical frameworks for the education of current and future conference interpreters. 


\section{References}

Agar, Michael 1994: Language shock: understanding the culture of conversation. New York: Perennial.

Agar, Michael 2006: Culture: Can you Take it Anywhere? Invited Lecture Presented at the Gevirtz Graduate School of Education, University of California at Santa Barbara. In International Journal of Qualitative Methods 5(2), 1-16.

AIIC 1998: Interpreting explained [online]. https://web.archive.org/web/20170125105953/http://aiic.net:80/node/2 (accessed 25 July 2017).

AIIC 2011: Related professions [online]. https://web.archive.org/web/20160419160110/http://aiic.net/p/4006/ (accessed 17 October 2017).

AIIC 2012a: Conference interpreting [online]. https://web.archive.org/web/20160916201607/http://aiic.net/p/4003/ (accessed 25 July 2017).

AIIC 2012b: Working languages [online]. https://web.archive.org/web/20160810094900/http://aiic.net/p/4004/ (accessed 17 October 2017).

Al-Zahran, Aladdin 2007: The consecutive conference interpreter as intercultural mediator: a cognitive-pragmatic approach to the interpreter's role (Doctoral dissertation). ProQuest Dissertations \& Theses Global database. (U514201 Ph.D.).

Angelelli, Claudia 2000: Interpreting pedagogy: A bridge long overdue. ATA Chronicle (November/December), 40-47.

Angelelli, Claudia 2004: Revisiting the interpreter's role: a study of conference, court, and medical interpreters in Canada, Mexico, and the United States. Amsterdam: John Benjamins.

Angelelli, Claudia 2008: Medical interpreting and cross-cultural communication. Cambridge: Cambridge University Press.

Arjona, Etilvia 1978: Intercultural Communication and the Training of Interpreters at the Monterey Institute of Foreign Studies. In Gerver, David/Sinaiko, H. Wallace (eds.), Language Interpretation and Communication. New York/ London: Plenum Press, 35-44.

Bahadır, Sebnem 2004: Moving in-between: the interpreter as ethnographer and the interpreting-researcher as anthropologist. In Meta 49(4), 805-821.

Baigorri-Jalón, Jesús 2015: The History of the Interpreting Profession. In Mikkelson, Holly/Jourdenais, René (eds.), The Routledge Handbook of Interpreting. London/ New York: Routledge Taylor \& Francis Group, 11-28.

Beaton, Morven 2010: Negotiating identities in the European Parliament: the role of simultaneous interpreting. In Baker, Mona/Pérez Calzada, María/Olohan, Maeve (eds.), Text and context. Essays of translation and interpreting in honor of Ian Mason. Manchester: St. Jerome, 117-138.

Berk-Seligson, Susan 2002: The bilingual courtroom: court interpreters in the judicial process (with a new chapter). Chicago: University of Chicago Press.

Bochner, Stephen 1981: The mediating person: bridge between cultures. Boston: G.K. Hall.

Boéri, Julie 2015: Key internal players in the development of the interpreting profession. In Mikkelson, Holly/Jourdenais, René (eds.), The Routledge Handbook of Interpreting. London/New York: Routledge, 29-44.

Bourne, Jenifer S. 2015: Overcoming intercultural challenges in interpreting: A case study on Chinese-English conference interpreting. (Unpublished doctoral dissertation). University of Maryland, College Park, Ann Arbor.

Bourne, Jenifer S. 2016: Exploring intercultural communication challenges: a case study on Chinese-English interpreting. In China Media Research 12(1), 14-24.

Bowen, David 1985: The Intercultural Component in Interpreter and Translator Training: A Historical Survey (doctoral dissertation). Georgetown University, Washington DC.

Bowen, David 2012: Interpreters and the making of history. In Delisle, Jean/Woodsworth, Judith (eds.), Translators through history. Amsterdam: John Benjamins, 247-284.

Bowen, David/Bowen, Margareta 2008: Interpreting yesterday, today, and tomorrow. American Translators Association scholarly monograph series. Amsterdam/Philadelphia: John Benjamins.

Brislin, Richard W. 1978: Contributions of Cross-Cultural Orientation Programs and Power. Analysis to Translation/ Interpretation. In Gerver, David/Sinaiko, H. Wallace (eds.), Language Interpretation and Communication. New York/ London: Plenum Press, 205-216.

Clifford, James/Marcus, George E. (1986/2010): Writing culture: the poetics and politics of ethnography. Berkeley, California: University of California Press.

Cronin, Michael 2002: The Empire talks back: orality, heteronomy and the cultural turn in interpreting studies. In Pöchhacker, Franz/Shlesinger, Miriam (eds.), The Interpreting Studies Reader. London/New York: Routledge, 387-397.

Cronin, Michael 2003: Translation and globalization. New York: Routledge. 
Dam, Helle V. 2017: The Changing Role of the Interpreter: Contextualising norms, ethics and quality standards. In Biagnini, Marta/Boyd, Michael/Monacelli, Claudia (eds.), Interpreter role, ethics and norms: linking to professionalization, London/New York: Routledge, 122-239.

Dam, Helle V./Zethsen, Karen K. 2013: Conference interpreters-the stars of the translation profession?: A study of the occupational status of Danish EU interpreters as compared to Danish EU translators. In Interpreting: International Journal of Research \& Practice in Interpreting 15(2), 229-259.

Davidson, Brad 2000: The interpreter as institutional gatekeeper: The social-linguistic role of interpreters in SpanishEnglish medical discourse. In Journal of Sociolinguistics 4(3), 379-405.

Davidson, Brad 2001: Questions in Cross-Linguistic Medical Encounters: The Role of the Hospital Interpreter. In Anthropological Quarterly 74(4), 170-178.

Delisle, Jean 1999: Introduction. In Roland, Ruth, Interpreters as Diplomats: A Diplomatic History of the Role of Interpreters in World Politics. Ottawa: University of Ottawa Press, 1-6.

Delisle, Jean/Woodsworth, Judith 2012: Translators through History: Revised edition. Philadelphia/Amsterdam: John Benjamins Publishing Company.

Diriker, Ebru 2004: De-/re-contextualizing conference interpreting: interpreters in the ivory tower? Amsterdam: John Benjamins.

Diriker, Ebru 2009: Meta-discourse as a source for exploring the professional image(s) of conference interpreters. In Hermes - Journal of Language and Communication Studies 42, 71-91.

Diriker, Ebru 2015: Conference interpreting. In Pöchhacker, Franz/Grbić, Nadja/Mead, Peter/ Setton, Robin (eds.), Routledge Encyclopedia of Interpreting Studies. Milton Park, Abingdon, Oxon: Routledge, 78-82.

EMCI 2015: EMCI Core Curriculum [online]. http://web.archive.org/web/20190121090444/https://www.emcinterpreting.org/course-structure (accessed 22 November 2017).

Eraslan, Seyda 2008: Cultural Mediator or Scrupulous Translator? Revisiting Role, Context and Culture in Consecutive Conference Interpreting. In Boulogne, Pieter (ed.), Translation and Its Others. Selected Papers of the CETRA Research Seminar in Translation Studies 2007. Leuven: KULeuven, 1-33.

Eraslan, Seyda 2011: International Knowledge Transfer in Turkey: the Consecutive Interpreter's Role in Context. (Doctoral dissertation), Rovira i Virgili University, Tarragona.

Fernández Ocampo, Anxo/Wolf, Michaela 2014: Framing the interpreter: towards a visual perspective. London: Routledge, Taylor \& Francis Group.

Gambier, Yves/van Doorslaer, Luc (eds.) 2013: The Handbook of Translation Studies. Amsterdam/ Philadelphia: John Benjamins.

Garzone, Giuliana/Viezzi, Maurizio 2002: Interpreting in the 21st century: challenges and opportunities. Selected papers from the 1st Forli Conference on Interpreting Studies. Amsterdam: John Benjamins.

Geertz, Clifford 1973: The interpretation of cultures: selected essays. New York: Basic Books.

Gentile, Paola 2013: The Status of Conference Interpreters: A Global Survey into the Profession. In Rivista Internazionale di Tecnica della Traduzione 15, 63-83.

Gentile, Paola 2017: Interpreting as a postmodern profession. A socio-historical approach. In Biagnini, Marta/Boyd, Michael/Monacelli, Claudia (eds.), Interpreter role, ethics and norms: linking to professionalization. London/New York: Routledge, 32-51.

Gile, Daniel 2001: The History of Research into Conference Interpreting: A Scientometric Approach. In Target 12(2), 297-321.

Goddard, Cliff 2005: The lexical semantics of culture. In Language Sciences 27(1), 51-73.

Goddard, Cliff 2006: Ethnopragmatics: understanding discourse in cultural context Applications of cognitive linguistics. Berlin/New York: Mouton de Gruyter.

Göhring, Heinz 1977: Interkulturelle Kommunikation: Die Überwindung der Trennung von Fremdsprachen- und Landeskundeunterricht durch einen integrierten Fremdsverhaltensunterricht”, in Kongressberichte der 8. Jahrestagung der Gesellschaft für Angewandte Linguistik GAL e. V. Vol.IV, Mainz, 9-13.

Grbić, Nadja 2010: "Boundary work" as a concept for studying professionalization processes in the interpreting field. In Translation \& Interpreting Studies: The Journal of the American Translation \& Interpreting Studies Association 5(1), 109-123.

Hall, Edward T. 1976/1989: Beyond culture (2. printing ed.). New York: Anchor Books.

Hall, Stuart 2008: Cosmopolitanism, Globalization and Diaspora. In Werbner, Pina (ed.), Anthropology and the New Cosmopolitanism: Rooted, Feminist and Vernacular Perspective. Oxford: Berg, 345-361.

Hatim, Basil/ Mason, Ian 1997: The translator as communicator. London: Routledge. 
Herbert, Jean 1952: The Interpreter's Handbook: How to Become a Conference Interpreter. Genève: Georg.

Hofstede, Geert 1984: National cultures revisited. In Asia Pacific Journal of Management 2(1), 22-28.

Holliday, Adrian 1999: Small Cultures. In Applied Linguistics 20(2), 237-264.

Holliday, Adrian 2011: Intercultural Communication \& Ideology. Los Angeles: SAGE Publications.

Inghilleri, Moira 2005: The Sociology of Bourdieu and the Construction of the 'Object' in Translation and Interpreting Studies. In The Translator 11(2), 125-145.

Jenks, Chris 1993/2005: Culture. London/New York: Routledge.

Jones, Roderick 1998: Conference interpreting explained. Manchester: St. Jerome.

Katan, David 2004: Translating cultures: an introduction for translators, interpreters and mediators. Manchester: St. Jerome Publishing.

Katan, David 2008: Translation as Intercultural Communication. In Munday, Jeremy (ed.), The Routledge companion to translation studies. London: Routledge, 74-92.

Katan, David 2013: Intercultural Mediation. In Gambier, Yves/van Doorslaer, Luc (eds.), The Handbook of Translation Studies. Amsterdam/ Philadelphia: John Benjamins, 84-91.

Kelly, Dorothy 2005: A handbook for translator trainers: a guide to reflective practice. London/ New York: Routledge.

Kondo, Masaomi 1990: What conference interpreters should not be expected to do. In The Interpreter's Newsletter 3, 59-65.

Kondo, Masaomi/Tebble, Hellen/Bistra, Alexieva/Dam V., Helle/Katan, David/Mizuno, Akira/Setton, Robin/Zalka, Ilona 1997: Intercultural Communication, Negotiation and Interpreting. In Gambier, Yves/Gile, Daniel/Taylor, Christopher (eds.), Conference interpreting: current trends in research: proceedings of the International Conference on Interpreting-What Do We Know and How?, Turku, August 25-27, 1994, Amsterdam: John Benjamins, 149-166.

Kramsch, Claire 1998: Language and Culture. Oxford: Oxford University Press.

Kumaravadivelu, B. 2008: Cultural globalization and language education. New Haven: Yale University Press.

Leal-Lobato, Ana I. 2017: Conference Interpreters: how to serve the cause of minorized communities in the new postmonolingual/ 'postmonodiscoursive' order. In Monzó-Nebot, Esther/Jiménez-Salcedo, Joan (eds.), Minoritized languages under a postmonolingual order. Castelló, Spain: Universitat Jaume I, 151-166.

Leal-Lobato, Ana I. (in progress): Conference interpreters as critical intercultural mediators. (Ongoing doctoral dissertation). Aarhus University, Aarhus.

Levy-Berlowitz, Ruth 2008: Interpreting in multicultural settings. In Bowen, David/Bowen, Margareta (eds.), Interpreting-yesterday, today, and tomorrow. Amsterdam, The Netherlands: John Benjamins, 117-121.

Liu, Minhua 2005: Kouyi yanjiu xin tan: Xin fangfa, xin guannian, xin qushi [Recent research into interpreting: New methods, concepts and trends]. In Interpreting: international journal of research and practice in interpreting 7(1), 146-155.

Marrone, Stefano 1993: Quality: A Shared Objective. In The Interpreters'Newsletter 5, 35-39.

Mason, Ian 2001: Triadic exchanges: studies in dialogue interpreting. Manchester, UK: St. Jerome.

Mesa, Anne-Marie 2000: The cultural interpreter: an appreciated professional. In Roberts, Roda P/Carr, Silvana E./ Abraham, Diana (eds.), Critical Link 2. Amsterdam: John Benjamins Publishing Company, 67-79.

Metzger, Melanie 2000: Sign language interpreting: deconstructing the myth of neutrality. Washington: Gallaudet University Press.

Mikkelson, Holly 2009: Interpreting is interpreting- or is it?. AIIC website [online]. http://aiic.net/p/3356 website/ (accessed 22 November 2017).

Monacelli, Claudia 2009: Self-preservation in simultaneous interpreting: surviving the role. Amsterdam: John Benjamins.

Morell Rodríguez, Jorge L. 2011: Toward the Development of a Metacognitive Intercultural Communicative Competence in the Education of Students of Interpreting: General Theoretical/ Pragmatic Foundations. In Translation \& Interpreting 3(1), 106-118.

Pöchhacker, Franz 1995: Writings and Research on Interpreting: A bibliographic Analysis. In The Interpreter's Newsletter 6, 17-31.

Pöchhacker, Franz 2001: Quality Assessment in Conference and Community Interpreting. In Meta 46(2), 410-425.

Pöchhacker, Franz 2016: Introducing Interpreting Studies. London: Routledge.

Pöchhacker, Franz/Grbić, Nadja/Mead, Peter/Setton, Robin (eds.) 2015: Routledge Encyclopedia of Interpreting Studies. Milton Park, Abingdon, Oxon: Routledge. 
Pym, Anthony/Shlesinger, Miriam/ Jettmarova, Zuzana (eds.) 2006: Sociocultural aspects of translating and interpreting. Amsterdam: John Benjamins.

Risager, Karen 2007: Language and culture pedagogy: from a national to a transnational paradigm. Clevedon/Buffalo/ Toronto: Multilingual Matters.

Rogers, Everett M./Hart, William B./Yoshitaka, Miike 2002: Edward T. Hall and the History of Intercultural Communication: The United States and Japan. In Keio Communication Review 24, 3-26.

Roland, Ruth 1999: Interpreters as Diplomats: A Diplomatic History of the Role of Interpreters in World Politics. Ottawa: University of Ottawa Press.

Roy, Cecilia 1993/2002. The problem with definitions, descriptions, and the role metaphors of interpreters. In Pöchhacker, Franz/Shlesinger, Miriam (eds.), The Interpreting Studies Reader. London/ New York: Routledge Taylor \& Francis Group, 344-353.

Roy, Cecilia 1999: Interpreting as a Discourse Process. Cary, United States: Oxford University Press.

Rudvin, Mette 2006: The cultural turn in Community Interpreting. A brief analysis of epistemological developments in Community Interpreting literature in the light of paradigm changes in the humanities. In Linguisstica Antverpiensia. New series- Themes in Translation Studies, 5 21-41.

Sawyer, David B. 2004: Fundamental aspects of interpreter education. Curriculum and assessment. Amsterdam/ Philadelphia: John Benjamins.

Scaglioni, Giulia 2013: Simultaneous Interpreting from German into Italian: The Importance of Preparation on a Selection of Cultural Items. In The Interpreter's Newsletter 18, 81-103.

Seeber, Kilian/Zegler, Christian 2007: 'Betrayal- Vice or Virtue? An Ethical Perspective on Accuracy in Simultaneous Interpreting'. In Meta 52(2), 290-298.

Seleskovitch, Danica/Lederer, Marianne 1989: Pédagogie raisonnée de l'interprétation. Paris: Didier/Luxembourg: Office des publications officielles des Communautés européennes.

Setton, Robin/Dawrant, Andrew 2016: Conference Interpreting: A Trainer's Guide. Amsterdam/ Philadelphia: John Benjamins.

Sewell, William H. 1999: The Concept(s) of Culture. In Bonnell, Victoria E./Hunt, Lynn. A. (eds.), Beyond the cultural turn: new directions in the study of society and culture. Berkeley: University of California Press, 35-51.

Snell-Hornby, Mary 1995: Translation studies: an integrated approach. Amsterdam: John Benjamin.

Sorrells, Kathryn 2013: Intercultural communication: globalization and social justice. Thousand Oaks: SAGE.

Straniero, Francesco S. 1998: Notes on cultural mediation. In The Interpreters' Newsletter 8, 151-168.

Taft, Ronald 1981: The role and personality of the mediator In Bochner Stephen (ed.), The mediating person: bridges between cultures. Cambridge, Massachusetts: Schenkman Publishing Company, 53-88.

Takeda, Kakyoko/Baigorri-Jalón, Jesús 2016: New insights in the history of interpreting. Amsterdam: John Benjamins.

Tomozeiu, Daniel/Kumpulainen, Minna 2016: Operationalising intercultural competence for translation pedagogy. In The Interpreter and Translator Trainer 10(3), 268-284.

Torikai, Kumiko 2009: Voices of the invisible presence: diplomatic interpreters in post-World War II Japan. Amsterdam: John Benjamins.

Torikai, Kumiko 2010: Conference interpreters and their perception of culture: From the narratives of Japanese pioneers. In Translation \& Interpreting Studies: The Journal of the American Translation \& Interpreting Studies Association $5(1), 75-93$.

Triandis, Harry C. 2001: Individualism-Collectivism and Personality. In Journal of Personality 69(6), 907-924.

Valdeón, Roberto A. 2013: Doña Marina/La Malinche: A historiographical approach to the interpreter/traitor. In Target 25(2), 157-179.

Viezzi, Maurizio 2013: Simultaneous and consecutive interpreting (non-conference settings). In Millán, Carmen/ Bartrina, Francesca (eds.), The Routledge handbook of translation studies. Milton Park, Abingdon: Routledge, 377-388.

Wadensjö, Cecilia 1998: Interpreting as interaction. London: Longman.

Wierzbicka, Anna 2005: In Defense of 'Culture'. In Theory \& Psychology 15(4), 575-597.

Wolf, Michaela/Fukari, Alexandra 2007: Constructing a sociology of translation. Amsterdam: John Benjamins.

Zwischenberger, Cornelia 2017: Professional self-perception of the social role of conference interpreters. In Biagnini, Marta/Boyd, Michael/Monacelli, Claudia (eds.), The changing role of the interpreter. Contextualizing norms, ethics and quality standards. New York/ London: Routledge, 52-73. 